\title{
KEDUDUKAN PERJANJIAN SEWA MENYEWA TANAH SEUMUR HIDUP YANG DIBUAT OLEH WARGA NEGARA INDONESIA DENGA N WARGA NEGARA ASING (Analisis Putusan Mahkamah Agung No. 2785K/Pdt/2011) Oleh \\ Gede Adhitya Ariawan \\ Made Subawa \\ I Made Udiana \\ Magister Kenotariatan Universitas Udayana \\ email : ariawanaditya@gmail.com
}

\begin{abstract}
ABSTRAK
UUPA tidak mengatur tentang jangka waktu pemberian hak sewa untuk bangunan. Jangka waktu pemberian hak sewa untuk bangunan hanya didasari oleh kesepakatan pihak pemberi sewa dengan pihak penyewa. Merujuk pada Pasal 1548 KUHPerdata disebutkannya "waktu tertentu" menimbulkan pertanyaan terkait apa yang dimaksud dengan waktu tertentu karena pada sewa menyewa tidak perlu disebutkan untuk berapa lama barang itu disewanya, asalkan sudah disetujui harga sewanya untuk satu hari, satu bulan atau satu tahun. Karenanya juga terdapat kekaburan terhadap rumusan Pasal 1548 KUHPerdata terkait dengan apa yang dimaksud "waktu tertentu" dan terhadap mutlak atau tidaknya suatu waktu didalam perjanjian sewa menyewa. Dalam praktek terdapat perjanjian sewa menyewa tanah tertanggal 5 Januari 2005 dengan mencantumkan kalausula seumur hidup dan terhadap perjanjian tersebut telah diputus dan dinyatakan sah oleh Mahkamah Agung dalam putusannya Nomor 2785K/Pdt/2011. Sementara itu menurut Pasal 1339 KUHPerdata suatu perjanjian mengikat juga terhadap kepatutan, kebiasaan dan Undang-Undang.

Permasalahan yang dapat diangkat dalam penelitian ini adalah apakah pencantuman klausula seumur hidup di dalam perjanjian sewa-menyewa tanah tertanggal 5 januari 2005 tidak bertentangan dengan asas kepatutan dalam ketentuan pasal 1339 KUHPerdata dan apakah dasar pertimbangan hakim di dalam memutus perkara perjanjian sewa-menyewa tanah yang dilangsungkan seumur hidup pada putusan Mahkamah Agung No. $2785 \mathrm{~K} / \mathrm{Pdt} / 2011$ telah mencerminkan syarat sahnya perjanjian menurut ketentuan pasal 1320 KUHPerdata

Penelitian ini menggunakan metode penelitian hukum normatif dengan jenis pendekatan yang digunakan meliputi pendekatan perundang-undangan, pendekatan kasus dan pendekatan analisis konsep hukum. Sumber bahan hukum yang digunakan dalam penelitian terdiri dari bahan hukum primer, bahan hukum sekunder dan bahan hukum tersier. Teknik pengumpulan bahan hukum menggunakan sistem kartu.

Hasil penelitian menunjukan bahwa pencantuman klausula seumur hidup pada perjanjian sewa menyewa tertanggal 5 Januari 2005 tidaklah patut atau bertentangan dengan asas kepatutan didalam Pasal 1339 KUHPerdata dan dasar pertimbangan Majelis Hakim dalam memutus perjanjian sewa menyewa tertanggal 5 Januari 2005belum mencerminkan syarat sahnya perjanjian didalam Pasal 1320 KUHPerdata. Oleh karenan itu kedudukan perjanjian sewa menyewa tertanggal 5 Januari 2005 menurut hukum perjanjian yang berlaku adalah batal demi hukum sehingga tidak memiliki kekuatan untuk mengikat para pihak.
\end{abstract}

Kata Kunci : perjanjian, sewa menyewa, seumur hidup, asas kepatutan.

\section{ABSTRACT}

The Basic Agrarian Law does not stipulate the term of building leases. The term of the lease is only based on the agreement between the lessor with the lessee. Referring to Article 1548 of the Civil Code, the explanation of "certain time" raises the question as to what is meant by a certain time because the lease does not need to be mentioned for how long the lease is rented, as long as the lease price is agreed whether it is for one day, one month or one year. Therefore, there is obscurity to the 
formulation of Article 1548 of the Civil Code relating to what is meant by "certain time" and to whether or not a certain time in the lease agreement is determined. In practice, there is a land lease agreement dated January 5, 2005 with a lifetime clause and the agreement has been terminated and declared valid by the Supreme Court in its decision No. 2785K/Pdt/2011. Meanwhile, under Article 1339 of the Civil Code an agreement also binds to the propriety, customs and laws.

The problems that can be raised in the research: is the inclusion of lifetime clause in land lease agreement dated January 5, 2005 is not contradictory to the principle of propriety in the provisions of Article 1339 Civil Code and is the basis of judge consideration in deciding the case of lifetime land lease agreement of the Supreme Court's decision No. $2785 \mathrm{~K} / \mathrm{Pdt} / 2011$ has reflected the terms of the validity of the agreement pursuant to Article 1320 of the Civil Code.

The study uses normative legal research methods with the types of approach used include the statute approach, case approach, analytical and conceptual approach. The sources of legal materials used in the study consist of primary, secondary and tertiary legal materials. The technique of collecting the legal materials is by using the card system.

The results showed that the inclusion of a clause on life in the lease agreement dated January 5, 2005 are inappropriate or contrary to the principles of propriety in Article 1339 of the Civil Code and the basic consideration of the judges in deciding the lease agreement dated January 5, 2005 has not yet reflected the terms validity of the agreement in Article 1320 of the Civil Code. Therefore the status of the lease agreement dated January 5, 2005 according to the applicable law is null and void so that it has no power to bind the parties.

\section{Keywords : Agreement, lease, lifetime, propriety principle}

\section{Pendahuluan}

\subsection{Latar Belakang Masalah}

Berdasarkan asas nasionalitas yang terkandung di dalam UUPA, pada dasarnya membedakan kepemilikan hak atas tanah antara subjek hukum Warga Negara Indonesia dan Warga Negara Asing. ${ }^{1}$ Warga Negara Asing yang berkedudukan di Indonesia hanya dapat mempunyai hak atas tanah salah satunya yaitu hak sewa untuk bangunan yang diatur dalam Pasal 44 UUPA. Pengertian hak sewa untuk bangunan, pemilik tanah menyerahkan tanah yang disewa oleh seseorang/badan hukum itu dalam keadaan kosong untuk kemudian si penyewa mendirikan bangunan yang secara yuridis juga dimilikinya. ${ }^{2}$

UUPA secara lebih lanjut tidak mengatur jangka waktu hak sewa untuk bangunan. Jangka waktu hak sewa untuk bangunan didasarkan

${ }^{1}$ Herlien Budiono, 2015, Kumpulan Tulisan Hukum Perdata, Buku Ketiga, Citra Aditya Bakti, Bandung, h. 261..

${ }^{2}$ Maria S.W. Sumardjono, 2005, Kebijakan Pertanahan Antara Regulasi dan Implementasi, Kompas, Jakarta, h.172 atas kesepakatan pemilik hak atas tanah dengan pemegang hak sewa di dalam suatu perjanjian sewa menyewa tanah. Ketentuan UUPA hanya mengatur terkait jangka waktu yang dapat diberikan terhadap hak guna usaha (HGU), hak guna bangunan (HGB), dan hak pakai. Pada ketentuan Pasal 29 UUPA menyebutkan bahwa jangka waktu HGU dapat diberikan paling lama 25 tahun dan terhadap usaha yang memerlukan waktu lebih lama dapat diberikan waktu paling lama 35 tahun dan atas permintaan pemegang hak dapat diperpanjang dengan waktu paling lama 25 tahun. Pada HGB, Pasal 35 UUPA menentukan jika jangka waktu HGB paling lama 30 tahun, dapat diperpanjang 25 tahun dan dapat diperpanjang paling lama 20 tahun. Selayaknya HGU dan HGB penegasan terhadap jangka waktu hak pakai diatur pada Pasal 45 Peraturan Pemerintah Nomor 40 tahun 1996 tentang HGU, HGB dan Hak Pakai yang menyebutkan jika hak pakai dapat diberikan 
untuk jangka waktu 25 tahun dan dapat diperpanjang 25 tahun serta dapat diperbaharui. Oleh karenanya, dapat dilihat bahwa terhadap jangka waktu hak sewa untuk bangunan tidak terdapat pengaturannya di dalam UUPA maupun pada Peraturan Pemerintah di bawahnya.

Pada ketentuan Pasal 1548 KUHPerdata menyebutkan sewa menyewa adalah "suatu persetujuan dengan mana pihak yang satu mengikatkan diri untuk memberikan kenikmatan suatu barang kepada pihak yang lain selama waktu tertentu, dengan pembayaran suatu harga yang disanggupi oleh pihak tersebut terakhir itu". Menurut R. Subekti, disebutkannya "waktu tertentu" di dalam uraian Pasal tersebut menimbulkan pertanyaan tentang apa yang dimaksud dengan waktu tertentu karena di dalam sewa menyewa tidak perlu disebutkan untuk berapa lama barang itu disewanya, asalkan sudah disetujui harga sewanya untuk satu hari, satu bulan atau satu tahun. ${ }^{3}$ Oleh karenanya, terdapat kekaburan terhadap rumusan Pasal 1548 KUHPerdata terkait dengan apa yang dimaksud serta mutlak atau tidaknya suatu waktu pada perjanjian sewa menyewa.

Pada prakteknya terdapat perjanjian sewa menyewa tanah yang dilangsungkan seumur hidup, yaitu pada perjanjian sewa menyewa tanah tertanggal 5 januari 2005 dimana Nyonya Ida Ayu Eka, Warga Negara Indonesia selaku pemilik sewa dan Tuan Renehan Michael john, Warga Negara Asing selaku pihak penyewa. Merujuk pada uraian tersebut adapun pertimbanganpertimbangan dari penulisan ini yaitu:

${ }^{3} \mathrm{R}$ Subekti, 2010, Hukum Perjanjian, PT. Intermsa, Jakarta, h.90.
Pertama, UUPA pada dasarnya melarang WNA untuk memiliki hak milik atas tanah. Dengan dilangsungkannya perjanjian seumur hidup (perjanjian tertanggal 5 Januari 2005) maka WNA dapat menguasai tanah dalam jangka waktu yang lama selayaknya pada hak milik.

Kedua, waktu merupakan unsur esensialia pada perjanjian sewa menyewa dan menurut Pasal 1339 KUHPerdata untuk menetapkan suatu waktu di dalam perjanjian sewa menyewa harus tunduk pada kepatutan daan kebiasaan yang berlaku (asas kepatutan).

Ketiga, Putusan Mahkamah Agung No. 2785 K/Pdt/ 2011 yang mengesahkan perjanjian sewa menyewa tanah tertanggal 5 Januari 2005 bertentangan dengan hukum perjanjian yang berlaku dan belum mencerminkan adanya kepastian hukum.

\subsection{Rumusan Masalah}

1. Apakah pencantuman klausula seumur hidup di dalam perjanjian sewa menyewa tanah tertanggal 5 Januari 2005 bertentangan atau tidak dengan asas kepatutan dalam ketentuan Pasal 1339 KUHPerdata

2. Apakah dasar pertimbangan hakim di dalam memutus perkara perjanjian sewa menyewa tanah yang dilangsungkan seumur hidup pada putusan Mahkamah Agung No. 2785 $\mathrm{K} / \mathrm{Pdt} / 2011$ telah mencerminkan syarat sahnya perjanjian menurut ketentuan Pasal 1320 KUHPerdata?

\subsection{Tujuan Penelitian}

Secara umum penelitian ini bertujuan untuk mengetahui bagaimana kedudukan perjanjian sewa menyewa tanah dengan mencantumkan klausula seumur hidup. Sementara itu, secara khusus tujuan dari penelitian ini yaitu untuk memahami keabsahan suatu perjanjian sewa tanah diantara WNI dan WNA yang dilangsungkan dengan mencantumkan klausula seumur hidup dan untuk mengetahui apakah dasar pertimbangan 
hakim di dalam memutus perkara perjanjian sewa menyewa tanah dengan kalusula seumur hidup telah mencerminkn syarat sahnya perjnjian.

\subsection{Manfaat Penelitian}

Secara teoritis penelitian ini diharapkan dapat memberikan sumbangan pemikiran dalam pegembangan ilmu hukum perjanjian. Secara praktis, diharapkan dapat menjadi pedoman bagi para pihak untuk melangsungkan perjanjian sewa menyewa tanah diantara WNI dan WNA.

\subsection{Landasan Teoritis}

Penelitian ini berlandaskan pada beberapa teori hukum, asasasas hukum dan konsep-konsep hukum yang akan diuraikan sebagai berikut :

a. Teori Mengikatnya Perjanjian

Van Dunne sebagai pencetus teori baru mengartikan perjanjian sebagai

'Suatu hubungan hukum antara dua pihak atau lebih berdasarkan kata sepakat untuk menimbulkan akibat hukum'. Teori baru tersebut tidak hanya melihat perjanjian semata tetapi, juga harus dilihat perbuatan sebelumnya atau yang mendahuluinya. Ada tiga tahap dalam membuat perjanjian menurut teori baru, yaitu tahap pracontractual, adanya penawaran dan penerimaan, tahap contractual, adanya persesuaian pernyataan kehendak antara para pihak dan tahap post contractual, yaitu pelaksanaan perjanjian. ${ }^{4}$ Menurut ketentuan Pasal 1338 KUHPerdata yang menyebutkan "Suatu perjanjian yang sah mengikat sebgai Undang-Undang". Dengan kata lain, kekuatan mengikat suatu perjanjian yang sah dapat dikualifikasikan mempunyai kekuatan yang mengikat setara dengan daya

${ }^{4}$ Salim H.S., 2011, Hukum Kontrak Teori \& Tehnik Penyusunan Kontrak, Cet. VIII, Sinar Grafika, Jakarta, h. 26. berlaku dan mengikatnya suatu Undang-Undang.

Merujuk pada perkataan "yang sah" maka kekuatan mengikat suatu perjanjian selayaknya Undang-Undang apabila perjanjian tersebut telah memenuhi syarat sahnya perjanjian. Sebaliknya, apabila perjanjian tidak sah maka perjanjian tersebut tidak memiliki kekuatan untuk megikat para pihak.

b. Teori Ratio Decidendi

Menurut Peter Mahmud Marzuki, ratio decidendi adalah alasan-alasan hukum yang digunakan oleh hakim untuk sampai kepada putusannya. ${ }^{5}$

Pertimbangan hukum (ratio decidendi) hakim pada suatu putusan merupakan mahkota bagi hakim yang harus dipertanggungjawabkan kepada Tuhan Yang Maha Esa, kepada pencari keadilan, dan masyarakat. Hakim bertanggung jawab atas putusan dan penetapan yang dibuatnya. Tinggi rendahnya kepercayaan masyarakat, sangat di tentukan dengan seberapa jauh argumentatifnya putusan hakim atas klaim, bahwa apa yang telah diputus oleh hakim harus dianggap benar (resjudicatapro veritate habetur). ${ }^{6}$

Pertimbangan hakim dalam memutus suatu perkara haruslah memuat alasan-alasan hukum yang cukup dan jelas. Putusan yang tidak memenuhi kriteria ini dapat dikatagorikan sebagai putusan yang tidak cukup pertimbangan (onvoldoendegemotiveerd). ${ }^{7}$

Terhadap putusan yang tidak cukup dasar pertimbangannya merupakan masalah yuridis sehingga sebagai akibatnya

${ }^{5}$ Peter Mahmud Marzuki, 2016, Penelitian Hukum, Prenada Media Group, Jakarta, h.158.

${ }^{6}$ Ibid, h. 11

${ }^{7}$ M. Yahya Harahap, 2006, Hukum Acara Perdata, Sinar Grafika, Jakarta, h.797 
putusan dapat dibatalkan pada tingkat banding atau kasasi. ${ }^{8}$

c. Asas-Asas Hukum Perjanjian

1. Asas Konsensualisme

$$
\text { Pada asasnya suatu }
$$

perjanjian yang timbul sudah dilahirkan sejak detik

tercapainya kesepakatan atau dengan perkataan lain perjanjian itu sudah sah apabila sudah tercapai kata sepakat mengenai hal yang pokok dan tidak diperlukan suatu formalitas. ${ }^{9}$

2. Asas Kebebasan Berkontrak

Berdasarkan asas kebebasan berkontrak maka, orang pada asanya dapat membuat suatu perjanjian dengan isi yang bagaimanapun juga selama tidak bertetangan dengan undangundang, kesusilaan dan ketertiban umum. ${ }^{10}$

3. Asas Pacta Sun Servanda

Semua perjanjian yang dibuat secara sah itu mengingat dan memiliki kekuatan hukum, sehingga wajib untuk dilaksanakan dan dapat dipaksakan pelaksanaanya.

4. Asas Itikad Baik

Di dalam hukum perjanjian itikad baik dapat ditafsirkan bahwa semua perjanjian harus sesuai dengan itikad baik yang digunakan untuk membatasi dan meniadakan suatu perjanjian.

5. Asas Kepatutan

Persetujuan tidak hanya mengikat untuk hal-hal yang secara tegas dinyatakan di dalamnya, tetapi juga untuk segala sesuatu yang menurut sifat perjanjian, diharuskan oleh kepatutan, kebiasaan dan undang-undang jadi setiap

${ }^{8}$ Ibid, h. 798

${ }^{9}$ R. Soeroso, 2011, Perjanjian Di Bawah Tangan Pedoman Praktis Pembuatan Dan Aplikasi Hukum, Sinar Grafika, Jakarta, h.16.

${ }^{10} \mathrm{~J}$ Satrio, 1993, Hukum Perikatan (perikatan pada umumnya), Alumni, Bandung, h.37. perjanjian harus mengandung unsur-unsur kebiasaan dan kepatutan

6. Asas Keseimbangan

Asas keseimbangan dapat dimaknai sebagai keseimbangan posisi dari para pihak yang mengadakan suatu perjanjian. Di dalam suatu perjanjian yang timbal balik kedudukan para pihak haruslah seimbang didalam menentukan hak dan kewajibannya.

d. Konsep Kepastian Hukum Menurut Peter Mahmud Marzuki, kepastian hukum mengandung dua pengertian, yaitu: ${ }^{11}$

1. Adanya aturan yang bersifat umum memuat individu mengetahui perbuatan apa yang boleh atau tidak boleh dilakukan.

2. Berupa keamanan hukum bagi ndividu dari kesewenangan pemerintah karena dengan adanya aturan yang bersifat umum itu, individu dapat mengetahui apa saja yang boleh dibebankan atau dilakukan oleh Negara terhadap individu. Dari uraian tersebut maka, dapat diketahui bahwa salah satu tujuan hukum yaitu memberikan kepastian hukum. Oleh karena itu perjanjian sebagai bentuk dari hukum harus mengandung kepastian hukum. Kepastian dalam perjanjian tercermin dari kekuatan mengikat suatu perjanjian merupakan undangundang bagi pembuatnya.

e. Konsep Perjanjian Sewa menyewa

Sewa-menyewa merupakan perjanjian konsensuil, artinya perjanjian telah sah mengikat para pihak setelah para pihak sepakat tentang barang dan harga. Barang yang diserahkan tidak untuk dimiliki, melainkan hanya untuk dinikmati kegunaannya. Unsur esensialia perjanjian sewamenyewa adalah sepakat para pihak, objek sewa, jangka waktu,

${ }^{11}$ Peter Mahmud Marzuki, 2008, Pengantar Ilmu Hukum, Kencana Prenada Media Group, Jakarta, h. 137. 
dan uang sewa. Unsur naturalia, seperti ketentuan sewa tidak putus dengan dijualnya objek sewa kecuali diperjanjikan sebelumnya. Unsur aksidentalia perjanjian sewa menyewa, seperti pilihan domisili hukum dan cara pembayaran.

\section{Metode Penelitian}

Jenis Penelitian ini merupakan penelitian hukum normatif yang beranjak dari dari kekaburan pada rumusan Pasal 1548 KUHPerdata dan tidak diaturnya jangka waktu sewa menyewa dalam UUPA. Penelitian ini menggunakan pendekatan perundang-undangan (statue approch), pendekatan kasus (case aproach) dan pendekatan analisis konsep hukum. (Analitical and conceptual Approach).

Sumber bahan hukum dalam penelitian ini terdiri dari bahan hukum primer, bahan hukum sekunder, dan bahan hukum tertier. Teknik pengumpulan bahan hukum dalam penelitian ini adalah dengan menggunakan sistem kartu (card system). Teknik analisis bahan hukum menggunakan teknik deskriptif, interprestasi, evaluasi dan argumentasi.

\section{KEABSAHAN PENCANTUMAN KLAUSULA HIDUP \\ PERJANJIAN MENYEWA TANAH \\ SEUMUR \\ DALAM SEWA}

\subsection{Sahnya Perjanjian Sewa} Menyewa Tanah Menurut Unsur-Unsur Perjanjian

Unsur-unsur

perjanjian

meliputi unsur esensialia, unsur naturalia, dan unsur aksidentalia. Unsur esensialia merupakan unsur yang paling penting karena dapat menentukan unsur naturalia dan aksidentalia. Selain itu, unsur esensialia merupakan unsur pokok yang harus ada di dalam setiap perjanjian. Apabila suatu perjanjian tidak memenuhi unsur esensialia maka perjanjian yang dibuat oleh para pihak tidak sah. Merujuk pada Pasal 1548 KUHPerdata jangka waktu sewa merupakan salah satu unsur esensialia dari perjanjian sewa menyewa.

Bertitik tolak dari ketentuan pasal Pasal 1570 KUHPerdata dan 1571 KUHPerdata maka untuk menentukan suatu waktu pada perjanjian sewa harus berpedoman pada kebiasaan yang berlaku dan waktu yang dimaksud adalah waktu yang dapat ditentukan dan pasti seperti misalnya untuk satu jam, satu hari, satu minggu, dan satu tahun. Oleh karenanya, terkait dengan perjanjian tertanggal 5 Januari 2005 klausula seumur hidup sebagai batas waktu, dapat dikatakan tidak memenuhi unsur esensialia dari perjanjian sewa menyewa karena pada dasarnya waktu tertentu yang dimaksud merupakan waktu yang dapat ditentukan. Meskipun matinya seseorang merupakan ketetapan waktu tetapi matinya seseorang bukanlah sebagai ketetapan waktu yang pasti. Jika unsur esensialia di dalam suatu perjanjian tidak ada perjanjian yang dibuat oleh para pihak tidak sah dan karena tidak sah maka tidak mengikat para pihak. ${ }^{12}$ Dengan demikian, sebagai konsekuensinya menurut hukum perjanjian tertanggal 5 januari 2005 tidak sah dan tidak mengikat para pihak.

\subsection{Pencantuman Klausula Seumur} Hidup Di dalam Perjanjian Menurut Asas Kepatutan.

Meski pada rumusan Pasal 1548 KUHPerdata tidak menentukan lebih lanjut terkait mutlak atau tidaknya waktu didalam perjanjian sewa menyewa, akan tetapi waktu merupakan

${ }^{12}$ Ismantoro Dwi Yuwono, 2013, Baca Buku Ini Sebelum Tanda Tangan Surat Perjnjian, Pustaka Yustisia, Yogyakarta, h.29 
unsur esensialia yang wajib ada di dalam suatu perjanjian sewa menyewa. Untuk menentukan suatu waktu tersebut menurut pasal 1339 KUHPerdata haruslah berpedoman pada ketentuan kepatutan dan kebiasaan yang berlaku. Untuk menentukan suatu waktu yang diperjanjikan patut atau tidak patut erat kaitannya dengan kebiasaan yang berlaku. Meski demikan, tidak semua kebiasaan yang berlaku dapat dikatakan patut untuk dimasukkan kedalam perjanjian. Merujuk pada penjelasan Pasal 44 dan 45 UUPA maka layaknya hak pakai, jangka waktu hak sewa untuk bangunan dilangsungkan untuk jangka waktu paling lama 25 tahun dan dapat diperpanjang untuk 25 tahun. Selain itu merujuk pula pada ketentuan Pasal 5 PP No. 41/1998 sebagaimana telah diganti menjadi PP No. 103/2015, Pasal 1592, 1593, 1597 KUHPerdata serta perjanjian sewa menyewa pembanding tertanggal 1 Maret 2017 selama 1 thn, 20 April 2017 selama 20 thn, 11 April 2017 selama 25 thn dan 7 Mei 2017 selama 5 thn. Maka, waktu yang dimaksud haruslah waktu yang pasti seperti untuk satu jam, satu hari, satu minggu dan satu tahun.

Oleh karenannya, jangka waktu sewa menyewa seumur hidup tidak lzim (tidak biasa) sehingga perjanjian tertanggal 5 Januari 2005 tidak patut dilangsungkan karena bertentangan dengan Pasal 1339 KUHPerdata. Menurut teori kekuatan mengikat perjanjian, suatu perjanjian yang sah akan mengikat para pihak selayaknya Undang-Undang dengan demikian karena perjanjian sewa menyewa tertanggal 5 Januari 2005 tidak sah maka tidak memiliki kekuatan untuk mengikat para pihak. Dengan kata lain, para pihak tidak terikat untuk

melaksanakan kewajibannya.

\subsection{Peran Notaris Di Dalam Mewujudkan Kepatutan Pada Perjanjian}

Notaris merupakan pejabat umum yang dalam menjalankan tugasnya bertindak madiri dan tidak memihak para pihak. Tugas utama notaris adalah membuat sutu alat bukti guna menjaamin terwujudnya kepastian hukum. Guna mewujudkan kepastian hukum bagi masyarkat peran notaris lebih bersifat prefentif yaitu mencegah terjadinya permasalahan hukum. Oleh Karena notaris merupakan pihak yang tidak memiliki kepentingan makaa keberadanya dapat menengahi kepentingaan para pihak dan mengarahkan para pihak untuk membuat suatu perjanjian yang patut.

Pada perjanjian sewa menyewa tertanggal 5 Januari 2005 terkait dengan kewenangan notaris menurut Pasal 15 ayat (2) huruf a dan b yaitu, legalisasi dan waarmerking. Pada waarmerking notaris hanya bertanggung jawab terhadap kepastian tanggal pendaftarannya saja. Pada legalisasi notaris bertanggung jawab untuk menjamin kepastian tanggal, kepastian pihak yang menandatangani atau membubuhkan cap jempol dan isi dari perjanjian tersebut.

Dalam hal ini notaris dapat dikatakan tidak cermat dan tidak menjalankan tugasnya dengan baik karena pada perjanjian yang diwaarmerking tersebut tercantumkan frasa selayaknya perjanjian yang dilegalisasi selain itu meskipun pada waarmerking notaris hanya berkewajiban untuk memastikan tanggal pendaftarannya saja dan tidak bertanggung jawab terhadap isi akan tetapi secara tidak langsung dapat dikatakan bahwa para pihak 
mewarmerking perjanjiannya pada notaris itu dapat diartikan telah menggunakan jasa yang diberikan oleh notaris dan sudah selayakya notaris menjalankan tugasnya dengan baik tidak terkecuali di dalam menjalankan kewenangannya didalam melegalisasi

mewaarmerking suatu perjanjian.

Oleh karena itu, notaris hendaknya menjalankan tugasnya dengan cermat, meskipun pada perjanjian itu hanya di waarmerking tidaklah di persalahkan apabila notaris melihat terlebih dahulu isi yang diperjanjikan oleh para pihak. sehingga jika perjanjian yang diwaarmerking tersebut dirasa bertentangan dengan kepatutan maka notaris berhak untuk mencegahnya.

Terkait perjanjian tertanggal 5 Januari 2005 maka, sesungguhnya secara moral notaris tetap memiliki tanggung jawab mengingat terdapat cap jabatan yang telah dibubuhkan pada perjanjian tersebut dan sebagai akibatnya akan berdampak buruk bagi kinerja notaris dimata masyarakat. Dengan demikian, peran notaris sangatlah penting karena dapat mencegah dialangsungkannya suatu perjanjian yang tidak patut.

\section{KASUS DAN ANALISIS}

\subsection{Uraian Kasus Perjanjian Sewa} Menyewa Tanah Tertanggal 5 Januari 2005

a. Kasus Posisi

Kasus menyewa ini bermula ketika Nyonya Ida Ayu Putu Eka Kartika WNI selaku pemilik sewa menyewakan sebidang tanah dengan sertifikat hak milik atas namanya sendiri kepada Tuan Renehan Michael John, Warga Negara Asing selaku Penyewa Berdasarkan perjanjian sewa menyew tertanggal 5 Januari 2005.
Perjanjian tersebut dilangsungkan dengan Bahasa Inggris. Terdapat klausula yang merugikan pemilik sewa yaitu:

Pasal 1: Perjanjian dimulai pada tanggal 5 Januari 2005 dan berlaku seumur hidup setelah penandatanganan pihak kedua (penyewa), Pasal 2: Harga sewa untuk seumur hidup ditetapkan sebesar Rp. 10.000.000,00 (sepuluh juta rupiah) oleh karena telah disepakati bersama maka harga sewa selama perjanjian berlangsung tidak dapat dinaikan maupun dirurunkan, dan Pasal 8 : Jangka waktu sewa menyewa seumur hidup yang dimaksud adalah seumur hidup pihak kedua. "seumur hidup" disini berarti awal sewa selama 15 tahun, diikuti perpanjangan secara otomatis, bebas dan tanpa ganti rugi, untuk setiap jangka waktu 20 tahun berikutnya sampai pihak kedua meninggal. Jika pihak kedua meninggal dalam jangka waktu 15 tahun terhitung sejak penandatanganan perjanjian ini, maka hak sewa akan dialihkan kepada pihak yang ditunjuk oleh pihak kedua untuk jangka waktu 20 tahun. Pihak kedua selama jangka waktu 15 tahun pertama dapat menjual kembali hak sewa beserta bangunan yang tertanam diatasnya akan tetapi ketika pemindahan kembali tersebut, perjanjian sewa-menyewa kembali menjadi sewa menyewa selama 20 tahun sewa terhitung sejak tanggal penjualan kembali. Sewa menyewa selama 20 tahun tersebut hanya dapat diperpanjang kembali dengan persetujuan tertulis pihak pertama dan dengan penggantian uang yang sesuai untuk perpanjangan sewa tersebut. Pihak kedua tidak berhak untuk menjual memindahkan perjanjian setelah 15 tahun terhitung sejak penandatanganan perjanjian awal ini. Untuk tidak dirugikan lebih 
banyak lagi kemudian atas kesepakatan kedua belah pihak, Nyonya Ida Ayu membuat perjanjian sewa menyewa kedua tertanggal 1 Oktober 2005. Pada perjanjian ini, masa berlaku sewa selama 10 tahun. Hingga akhirnya pemilik sewa mengajukan gugatan ke Pengadilan Negeri Gianyar, memohon untuk menyatakan menyatakan perjanjian sewa menyewa tanah menggunakan Bahasa Inggris tertanggal 5 Januari 2005 antara penggugat dengan tergugat tidak sah dan cacat hukum serta patut untuk dibatalkan, menyatakan sah serta mempunyai kekuatan hukum mengikat perjanjian sewa menyewa kedua tertanggal 1 Oktober 2005. Di dalam persidangan, Tuan Michael John selaku tergugat mengajukan gugatan balik (rekonpensi) memohon untuk menyatakan perjanjian sewa menyewa tanah tertanggal 5 Januari 2005 sah dan mengikat, menyatakan tidak sah dan tidak mengikat dan patut dibatalkan perjanjian kedua tertanggal 1 Oktober 2005 karena perjanjian kedua ini merupakan rekayasa dari penggugat.

b. Dasar Pertimbangan Hakim

Menurut majelis hakim dalam perjanjian ke dua tertanggal 1 Oktober 2005 yang menjadi objek adalah rumah sedangkan pada perkara ini yang menjadi objek adalah tanah sebagaimana yang telah diakui oleh para pihak bahwa pada perjanjian sebelumnya tertanggal 5 Januari 2005 atas hal tersebut Majelis Hakim berpandangan bahwa perjanjian kedua tertanggal 1 Oktober 2005 tidak sah karena tidak memuat seara detail objek (pasal 1320 KUHPerdata) sewa sehingga sudah selayakya perjanjian tersebut batal demi hukum.

Terhadap perjanjian sewa menyewa tertanggal 5 Januari
2005 sahnya perjanjian menurut pasal 1320 KUHPerdata terdapat empat syrat yang mana majelis hakim menguraikan sebgai berikut:

1. Adanya kesepakatan, Majelis Hakim berpandangan bahwa penggugat dan tergugat keduanya telah menandatangani perjanjian sewa menyewa tertanggal 5 Januari 2005 dan terhadap fakta ini tidak dibantah oleh keduanya dan dari keterangan saksi-saksi tidak terungkap adanya paksaan, kekhilafan, atau peipuan yang dilakakukan oleh salah satu pihak.

2. Kecakapan, pada asasnya setiap orang yang sudah dewasa dan sehat pikirannya adalah cakap menurut hukum. Dari keterangan saksi saksi dan terlihat secara nyata oleh Majelis Hakim di muka persidangan bahwa para pihak sebagai subyek perjanjian adalah orang yang sudah dewasa dan sehat pikirannya.

3. Hal Tertentu, mengenai sebidang tanah dengan sertifikat hak milik No. 1414 atas nama penggugat sendiri.

4. Sebab yang halal, terhadap dalil penggugat yang menyebutkan perjanjian tertanggal 5 Januari 2005 bertentangan dengan ketentuan pasal 5 PP No.41/1996 tentang kepemilikan rumah tempat tinggal atau hunian oleh orang asing yang menyebutkan jangka waktu sewa tidak lebih dari 25 tahun. Atas hal ini Majelis Hakim berpandangan bahwa yang menjadi objek sewa adalah tanah dan bukanlah rumah. Dari pertimbanganpertimbangan di atas, Majelis Hakim berpendapat bahwa perjanjian sewa menyewa tertanggal 5 Januari 2005 yang menggunakan Bahasa Inggris adalah tidak cacat hukum sehingga sah secara hukum serta mempunyai kekuatan hukum mengikat. Pada Tingkat Banding Putusan Pengadilan Negeri Gianyar dikuatkan Oleh Pengadilan Tinggi Denpasar sehingga dasar pertimbangan hakim Pengadilan Negeri Gianyar pada putusan Nomor: 53/Pdt.G/2010/PN.Gir diambil alih 
dan dianggap sebagai dasar pertimbangan Majelis Hakim Pengadilan Tinggi Denpasar pada putusanya Nomor: 39/PDT/2011/PT.DPS. Pada tingkat kasasi menurut Mahkamah Agung pada putusannya Nomor: 2785 $\mathrm{K} / \mathrm{Pdt} / 2011$ berpandangan bahwa putusan judex facti telah tepat dan benar, serta alasan-alasan kasasi yang diajukan mengenai hasil pembuktian tidak dapat dipertimbangkan dalam pemeriksaan tingkat kasasi sehingga permohonan kasasi yang diajukan harus ditolak.

\subsection{Analisis Kasus}

Putusan Majelis Hakim yang mengesahkan perjanjian sewa menyewa tertanggal 5 Januari 2005 belum mencerminkan syarat sahnya perjanjian pada Pasal 1320 KUHPerdata. Hal ini dapat dilihat bahwa Majelis Hakim tidak mempertimbangkan ketentuan asas kepatutan yang terkandung pada Pasal 1339 KUHPerdata dan ketentuan Pasal 31 UU No. 24/2009 yang menyebutkan bahwa perjanjian yang melibatkan Warga Negara Asing dapat dilangsungkan dengan Bahasa Inggris dan wajib juga membuat dalam Bahasa Indonesia.

Salah satu syarat sahnya perjanjian dalam Pasal 1320 KUHPerdata adalah sebab yang halal. Sebab yang halal merupakan bagian dari syarat objektif. Sebab yang halal dapat diartikan bahwa suatu perjanjian tidak bertentangan dengan undangundang, ketertiban umum dan kesusilaan. Oleh karena perjanjian tersebut tidak memenuhi ketentuan kepatutan pada Pasal 1339 KUHPerdata dan ketentuan Pasal 31 UU No. 24/2009 yang mana ketentuan tersebut merupakan ketentuan yang diisyaratkan oleh undang-undang maka dapatlah dikatakan bahwa perjanjian tersebut tidak memenuhi syarat sahnya perjanjian tentang sebab yang halal.

Majelis Hakim juga tidak mempertimbangkan lebih lanjut terkait ketentuan kecakapan para pihak atas objek perjanjian mengingat salah satu pihak adalah Warga Negara Asing sehingga menurut ketentuan UUPA Warga Negara Asing yang dapat memperoleh hak atas tanah di Indonesia adalah yang berkedudukan di Indonesia. Secara singkat, berkedudukan dapat diartikan bahwa Warga Negara Asing tersebut telah tinggal di Indonesia dan kehadirannya memberikan manfaat yang dapat dibuktikan melalui KITAB atau KITAS. Degan demikian, jika pada saat dilangsungkannya perjanjian sewa tertanggal 5 Januari 2005 tergugat tidak berkedudukan di Indonesia maka akan membuat perjanjian tersebut bertentangan dengan ketentuan UUPA. Selain itu, dapat dilihat juga Majelis Hakim tidak mempertimbangkan secara terperinci atas ada atau tidaknya cacat kehendak pada kesepakatan yang terjadi diantara para pihak. Hal ini sangat penting untuk dipertimbangkan karena sesungguhnya pada perjanjian teranggal 5 Januari 2005 terdapat penyalahgunaan keadaan sehingga mengakibatkan cacat kehendak pada kata sepakat dari para pihak. Penyalahgunaan keadaan menurut kamus istilah hukum Fockema Andreae, misbruik van omstandigheden adalah suatu keadaan untuk menyalahgunakan keadaan darurat orang lain, ketergantungannya (ketidakberdayaannya), kesembron oannya, keadaan akalnya yang tidak sehat, atau ketidak pengalamannya dalam 
mengerjakan perbuatan hukum yang merugikan dirinya. ${ }^{13}$

Penyalahgunaan keadaan yang terjadi pada perjanjian tertanggal 5 Januari 2005 dimana Saat seseorang menggunakan posisi psikologis dominannya yang digunakan secara tidak adil untuk menekan pihak yang lemah supaya mereka menyetujui sebuah perjanjian yang sebenarnya mereka tidak ingin menyetujuinya. Sehingga sejak awal pada prjanjian ini sesungguhnya salah satu pihak telah mengetahui posisinya yang lebih kuat seperti penggugat yang telah menyadari kelemahan dari pihak tergugat selaku Warga Negara Asing yang tidak dapat dengan mudah memiliki hak atas tanah di Indonesia maupun sebaliknya pihak tergugat telah menyadari kelemahan penggugat yang menaruh keyakinan (kepercayaan) pada tergugat dan kelemahan atas pemahaman bahasa yang dimiliki. Terlepas dari pihak yang mana melakukan penyalahgunaan keadaan namun satu hal yang dapat disimpulkan bahwa pada perjanjian tertanggal 5 Januari 2005 telah terjadi penyalahgunaan keadaan. Adanya cacat kehendak tersebutlah yang mengakibatkan substansi perjanjian tertanggal 5 Januari 2005 menjadi tidak patut. Oleh karena itu menurut hukum perdata yang berlaku perjanjian sewa menyewa tanah tertanggal 5 januari 2005 adalah batal demi hukum sehingga sesungguhnya tidak mengikat para pihak.

Terhadap putusan majelis hakim dimana Menurut teori ratio decidendi dalam suatu putusan hakim harus memuat dasar dan alasan yang jelas serta memuat pasal-pasal tertentu dari peraturan perundang-undangan sehingga putusan Majelis Hakim tersebut

${ }^{13}$ Rendy Saputra, op.cit, h. 52. dapat dikatakan tidak berdasar pada alasan yang jelas dan rinci dengan kata lain putusan tersebut dijatuhkan tidak berdasar pada pertimbangan yang cukup (onvoldoende gemotiveerd). Sebagai konsekuensinya putusan dapat dibatalkan pada tingkat peradilan yang lebih tinggi baik pada tingkat banding maupun kasasi. Dikuatkannya putusan Pengadilan Negeri Gianyar pada tingkat banding dan kasasi tidak mencerminkan kepastian hukum. Oleh karena itu menurut teori ratio decidendi dan guna terwujudnya kepastian hukum perjanjian tertanggal 5 Januari 2005 haruslah dinyatakan batal demi hukum oleh Majelis Hakim. Meskipun menurut adagium resjudicata pro veritate habetur apa yang diputus oleh hakim harus dianggap benar, suatu perjanjian tetaplah tidak dapat bertentangan dengan kepatutan jika dikemudian hari terdapat perjanjian serupa, maka menurut ketentuan hukum perdata hal tersebut tidak dapat dibenarkan karena suatu perjanjian yang bertentangan dengan kepatutan adalah batal demi hukum.

\section{Kesimpulan dan Saran \\ 5.1 Kesimpulan}

Berdasarkan pembahasan pada bab-bab yang telah diuraikan sebelumnya, maka dapat ditarik kesimpulan, bahwa:

1. Pencantuman klausula seumur hidup di dalam perjanjian sewa menyewa tertanggal 5 Januari 2005 tidaklah patut atau bertentangan dengan asas kepatutan di dalam Pasal 1339 KUHPerdata karena Asas kepatutan pada prinsipnya menitikberatkan pada kebiasaan umum yang ada dimasyarakat sehingga untuk menetapkan waktu pada perjanjian sewa menyewa harus mngikuti kebiasaan yang berlaku umum dimasyarakat. Dari ketentuan 
perundang-undangan dan perjanjian sewa menyewa tanah tertanggal 1 Maret 2017, 20 April 2017, 11 April 2017 dan 7 Mei 2017 secara lazim suatu ketetapan waktu di dalam perjanjian sewa menyewa adalah waktu yang dapat ditentukan dan pasti seperti untuk satu hari, satu minggu, satu bulan dan satu tahun selayaknya pada pengaturan jangka waktu hak pakai yang dapat diberikan paling lama untuk jangka waktu 25 tahun, dapat diperpanjang 25 tahun dan dapat diperbaharui, mengingat pada penjelasan pasal 44 dan 45 UUPA menyebutkan bahwa hak sewa untuk bangunan merupakan hak pakai yang mempunyai sifat khusus.

2. Pertimbangan Majelis Hakim tidak mencerminkan syarat sahnya perjanjian didalam Pasal 1320 KUHPerdata karena tidak dipertimbangkannya ketentuan kepatutan pada Pasal 1339 KUHPerdata, adanya cacat kehendak pada kesepakatan para pihak dan kewenangan para pihak atas objek perjanjian oleh Majelis Hakim maka sesungguhnya perjanjian sewa menyewa tanah tertanggal 5 Januari 2005 bertentangan dengan syarat sebab yang halal sehingga kedudukan perjanjian sewa menyewa tanah tertanggal 5 Januari 2005 menurut hukum perjanjian adalah batal demi hukum.

\subsection{Saran}

Adapun saran yang dapat diberikan terkait dengan penelitian ini ialah :

1. Disarankan kepada pemerintah hendaknya membentuk suatu peraturan terkait jangka waktu hak sewa untuk bangunan dengan mengikuti jangka waktu selayaknya pada pengaturan jangka waktu pada hak pakai guna terwujudnya suatu kepastian hukum.

2. Disarankan kepada Majelis Hakim dalam memutus suatu perkara hendaknya menggali seluruh ketentuan hukum yang ada dan menuangkannya pada pertimbangan hukum. Ketetuan kepatutan sudah selayaknya selalu menjadi pertimbangan hakim didalam memutus suatu gugatan perjanjian karena sudah sepatutnya suatu perjanjian mencerminkan nilai-nilai yang ada di masyarakat guna terwujudnya keadilan sebagai tujuan dari hukum itu sendiri.

\section{Buku}

\section{DAFTAR PUSTAKA}

Budiono, Herlien, 2015, Kumpulan Tulisan Hukum Perdata, Buku Ketiga, Citra Aditya Bakti, Bandung.

Dwi Yuwono Ismantoro, 2013, Baca Buku Ini Sebelum Tanda Tangan Surat Perjnjian, Pustaka Yustisia, Yogyakarta

H.S., Salim, 2011, Hukum Kontrak Teori \& Tehnik Penyusunan Kontrak, Cet. VIII, Sinar Grafika, Jakarta.

Marzuki, Peter Mahmud, 2008, Pengantar Ilmu Hukum, Kencana Prenada Media Group, Jakarta. , 2016, Penelitian Hukum, Prenada Media Group, Jakarta.

Satrio, J, 1993, Hukum Perikatan (perikatan pada umumnya), Alumni, Bandung.

Soeroso, R, 2011, Perjanjian Di Bawah Tangan Pedoman Praktis Pembuatan Dan Aplikasi Hukum, Sinar Grafika, Jakarta.

Subekti, R, 2010, Hukum Perjanjian, PT. Intermsa, Jakarta.

Sumardjono, Maria S.W., 2005, Kebijakan Pertanahan Antara Regulasi dan Implementasi, Kompas, Jakarta.

Yahya, M. Harahap, 2006, Hukum Acara Perdata, Sinar Grafika, Jakarta. 


\section{Peraturan Perundang-Undangan}

Kitab Undang-Undang Hukum Perdata

Undang-Undang Nomor 5 Tahun 1960 Tentang Peraturan Dasar Pokokpokok Agraria. (Lembaran Negara Republik Indonesia tahun 1960 Nomor 104, Tambahan Lembaran Negara Republik Indonesia Nomor 20430).

Undang-undang Nomor 24 tahun 2009 Tentang Bendera, Bahasa, dan Lambang Negara Serta Lagu Kebangsaan. (Lembaran Negara Republik Indonesia Tahun 2009 Nomor 109, Tambahan Lembaran Negara Republik Indonesia Nomor 5035).

Undang-Undang Nomor 2 tahun 2014 Tentang Perubahan Atas UndangUndang Nomor 30 tahun 2004 Tentang Jabatan Notaris. (Lembaran Negara Republik Indonesia Tahun 2004 Nomor 3, Tambahan Lembaran Negara Republik Indonesia Nomor 5491).

Peraturan Pemerintah Nomor 40 Tahun 1996 Tentang Hak Guna Usaha, Hak Guna Bangunan, Dan Hak Pakai Atas Tanah. (Lembaran Negara Republik Indonesia Tahun 1996 Nomor 58, Tambahan Lembaran Negara Republik Indonesia Tahun 1996 Nomor 3643).

Peraturan Pemerintah Nomor 103 tahun 2015 tentang pemilikan rumah tinggal atau hunian oleh orang asing yang berkedudukan di Indonesia. (Lembaran Negara Republik Indonesia tahun 2015 Nomor 325, Tambahan Lembaran Negara Republik Indonesia Nomor 5793). 